\title{
MAGYARORSZÁGI TELEPÜLÉSEK VIZSGÁLATA KÖZLEKEDÉSI ÉS TÁVKÖZLÉSI ELLÁTOTTSÁG ALAPJÁN
}

(The examination of Hungarian settlements by their provision with transport and telecommunication)

\section{MILETICS PÉTER}

A kőzlekedési és távközlési rendszerek az infrastruktúra részeként igen jelentős szerepet játszanak az egyes települések megítélésében. Megnövelik az egyre nagyobb fontosságú információk áramlásának sebességét, és egyáltalán az információcsere lehetőségeit. Emellett meghatározóak a népesség számára, lehetővé téve annak térpályáinak kiterjesztését, egyúttal a lakosság mobilitási indexének növekedését.

A közlekedés és a távközlés lehetỏséget biztosit új vállalkozások telepítésére az egyes településeket illetően, ezáltal növelhetik az általunk vizsgált nagyközségek potenciális értékét.

Mindezen infrastrukturális elemek megléte önmagában még nem jelenti azt, hogy az adott település alkalmas önálló térszervezó funkciók ellátására, de esetleges hiảnyuk sokkal inkább negatívan hat megitélésúkre, mint a fenntartásukból, illetve megteremtésủkbỏl adódó ténylegesen létezỏ problémák.

A vizsgálatba bevont 177 nagyközség kiválasztása előzetes egyeztetés alapján tơrtént. Célunk az volt, hogy a nagyközségeket valamilyen, általunk önkényesen kialakított mutatók segítségével rangsoroljuk és az így hierarchizált településeket oly módon próbáljuk beilleszteni a magyar településhálózat rendszerébe, hogy ez alapján bizonyos következtetéseket tudjunk levonni.

\section{Vizsgálati módszerek}

A vizsgálathoz felhasználtuk a Magyar Köztársaság területére érvényes, a Magyar Államvasutak által kiadott 1995-96-os hivatalos menetrendet, a MATÁV 1995-96-os telefonkönyveit, a WESTEL és a PANNON GSM által rendelkezésünkre bocsátott hálózati térképeket, valamint a VOLÁN EGYESÜLÉS 1995. május 28-tól 1996. június 1ig érvényes, hivatalos nemzetközi, távolsági és megyei menetrendeket.

A felhasznált forrásanyagokból a következó adatsorokat vettük figyelembe:

- az adott telepủlést bekapcsolták-e a távhívás rendszerébe

- az adott települést bekapcsolták-e a WESTEL GSM rendszerébe

- az adott telepúlést bekapcsolták-e a PANNON GSM rendszerébe

- az adott telepủlés rendelkezik-e vasútállomással

- az adott településen megálló személyszállító vonatok száma

- az adott telepũlés távolsága a vasúti fövonaltól

- az adott telepủlést érintő nemzetközi és távolsági autóbuszok járatszáma 
- az adott települést érintő megyei autóbuszok járatszáma

Mivel célunk elsősorban az egyes települések mennyiségi ellátottságának vizsgálata volt, ezért - és a rendelkezésünkre álló idő rövidsége miatt - ezen mutatók alapján képeztünk értékpontokat, amelyek alapján öt csoportba soroltuk be a nagyközségeket. A valamennyi településre (177) érvényes értékpontok kialakítása a következök szerint történt meg:

- ha az adott telepulést bekőtotték a távhívás rendszerébe:

- ha az adott települést nem kőtơtték be a távhívás rendszerébe:

5 pont

- ha a település bekapcsolódott az alternativ kommunikációs rendszerekbe: - WESTEL GSM

0 pont

- ha a település nem kapcsolódott be az alternativ kommunikációs rendszerbe: PANNON GSM

- ha a település rendelkezik vasútállomással:

- ha a telepủlés nem rendelkezik vasútállomással:

- a település vasúti járatellátottsága: - személyszállító vonatok száma:

2 pont

2 pont

0 pont

(a gyorsvonatok kétszeres szorzóval szerepelnek)

- a vasúti fövonal elérhetősége az adott telepủlésröl: ( itt az alapján alakítottuk ki a pontszámokat, hogy az adott nagykőzség milyen távolságra fekszik attól az állomástól, ahol a fôvonalra csatlakozás megtőrténhet )

- ha a telepullés a fỏvonalon fekszik és van gyorsvonati megállóhely:

2 pont

0 pont

- ha a távolság $1-9$ kilométer:

- ha a távolság 10-19 kilométer:

15 pont

10 pont

- ha a távolság 20-29 kilométer:

9 pont

- ha a távolság 30-39 kilométer:

- ha a távolság 40-49 kilométer:

8 pont

- ha a távolság 50-59 kilométer:

7 pont

- ha a távolság 60-69 kilométer:

6 pont

- ha a távolság 70-79 kilométer:

5 pont

- ha a távolság 80-89 kilométer:

4 pont

- ha a távolság 90-99 kilométer:

- ha a távolság 100 kilométernél nagyobb:

Megjegyzes: - a vizsgálatba vont településeknél a legnagyobb távolság 92 kilométer volt.

- a telepuilés ellátottsága autóbuszjáratokkal: - járatszám: (a nemzetkơzi és távolsági járatok kétszeres szorzóval szerepelnek)

1-1 pont

$\mathrm{Az}$ ismertetett pontértékek alapján valamennyi vizsgált településhez meghatározott összértéket rendeltünk, melyet egyszerü összeadási müvelettel számítottunk ki. Az értékskála két végpontjára került települések kapták a legalacsonyabb, illetve a legmagasabb értéket. A legrosszabb helyre került Tarcalt (mindössze 4 értékpont) 0 pontra értékeltük, míg a közlekedés- és távközlés-rendszerellátottság alapján legoptimálisabb helyzetben lévö település, Diósd (504 értékpont) 100 pontot kapott. A kialakított pontértékeknek megfelelỏen a vizsgálatba bevont nagyközségeket öt, egymástól eltérỏ elemszámú kategóriába soroltuk be. A településeket eltérő jelkulcsok segítségével térképre vittük, érzékeltetve a kategorizált 177 nagyközség térbeli megoszlását (I. ábra).

\section{Megjegyzések}

Mivel vizsgálataink nem átfogó jellegüek voltak, mindenképp szükségesnek tartanánk, hogy a jelenlegi korlátozott mélységủ kutatásokat kövesse egy alaposabb településelemzés. Fontosnak tartjuk megjegyezni azt is, hogy az általunk felhasznált mutatók elsősorban az adott települések mennyiségi és kevésbé minőségi jellemzését tette lehetỏvé. 


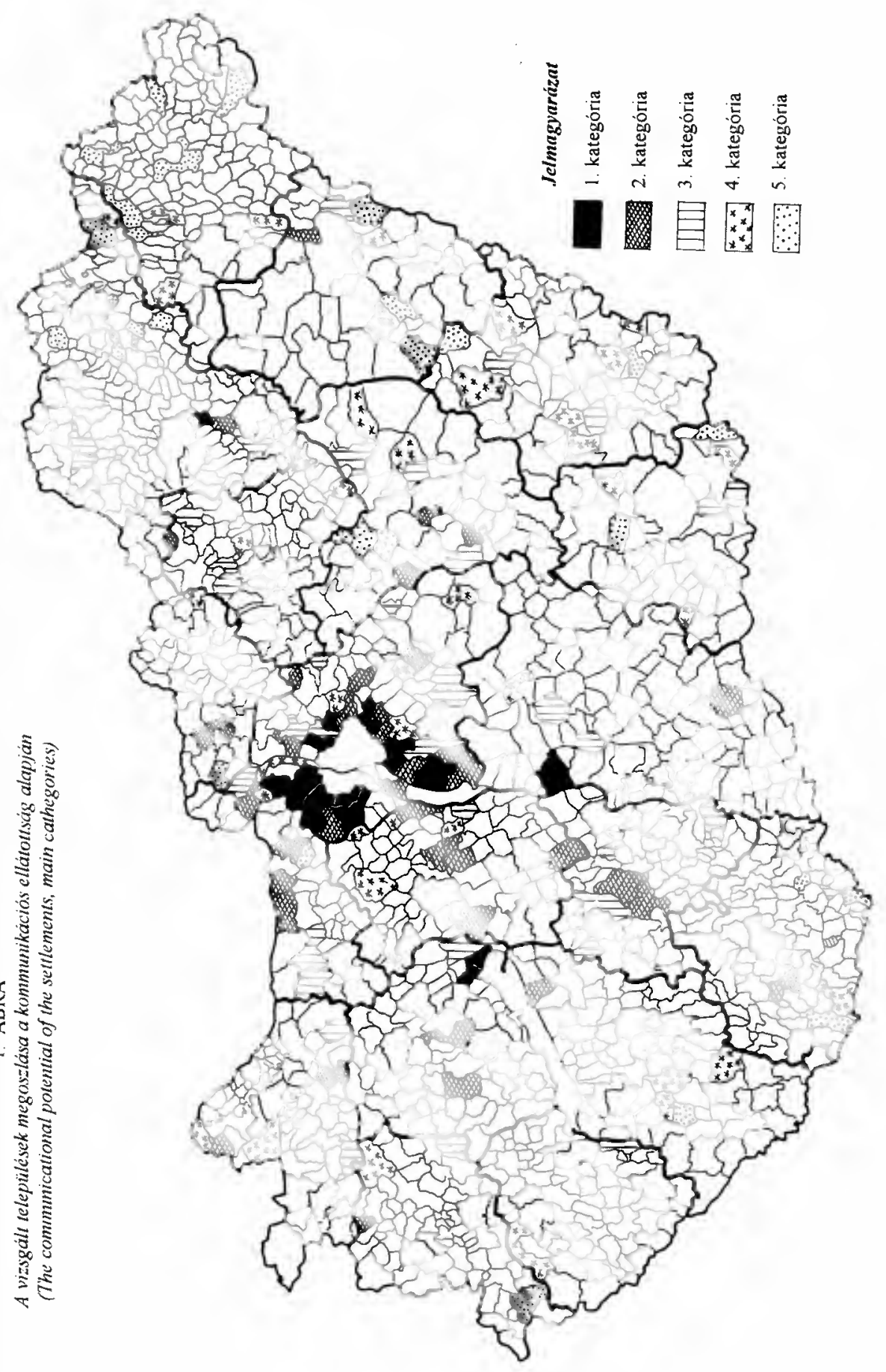


Úgy véljük, hogy a közlekedés és távközlés rendszerének vizsgálata önmagában csak szuikséges, de nem elégséges feltétele a vizsgált nagyközségek rangsorolásának. Az adott települések egymáshoz viszonyitott, valós besorolását csak kellö mélységú és komplex vizsgálatok alapján tartjuk lehetségesnek, melyben a közlekedés és a távközlés értékei csak a kutatás egyik elemét képeznék.

A kutatás során az is nyilvánvalóvá vált, hogy a hivatalos menetrendek kezelése igen nehézkes és számos esetben félrevezetó adatokat tartalmaznak. Mivel a WESTEL és a PANNON GSM csak egy-egy hálózati térképpel segítette munkánkat, ezért több esetben csak becslésekre hagyatkozhattunk. Azzal is tisztában vagyunk, hogy a felhasznált telefonkönyvek az 1994. december 31-i állapotokat tükrözik, de ennél frissebb hiteles adatokhoz nem sikerült hozzajutnunk.

A vizsgált települések - amelyek kiválasztásában nem vettünk részt - térstruktúrája erós Budapest-centrikusságot tükröz, amelyet számításaink is megerősitettek. A kutatások azt látszottak igazolni, hogy Pest megyében, pontosabban a budapesti monocentrikus agglomeráció közelében elhelyezkedő nagyközségek kiemelkedő közlekedési és távközlési ellátottsággal rendelkeznek. Ez az értékelés véleményünk szerint némileg ellentmondásos és félrevezetö ${ }^{1}$.

Az adatokból kitünik, hogy a vizsgálatba bevont 177 település közül csak az elsö két kategóriába soroltak rendelkeznek megfelelőnek mondható közlekedési és távközlési infrastruktúrával. Megállapítható továbbá az is, hogy Pest megye az első négy kategóriản belül meghatározó súllyal szerepelt (felülreprezentált) és csak az utolsóban "veszítette" el vezető helyét (1. és 2. táblázat).

\section{TÁBLÁZAT}

A megyék százalékos részesedése kategóriákra kivetítve

(The share of counties by cathegories)

\begin{tabular}{|l|l|l|l|l|l|}
\hline \multicolumn{1}{|c|}{ Megye } & I. kategória & \multicolumn{1}{|l}{ II. kategória } & III. kategória & IV. kategória & V. kategória \\
\hline Baranya & - & $2=28,57 \%$ & $1=14,28 \%$ & $1=14,28 \%$ & $3=42,85 \%$ \\
\hline Bács-Kiskun & $1=16,66 \%$ & $2=33,33 \%$ & $2=33,33 \%$ & $1=16,66 \%$ & - \\
\hline Békés & - & - & $2=20,00 \%$ & $6=60,00 \%$ & $2=20,00 \%$ \\
\hline Borsod-Abaúj-Zemplén & $1=7,14 \%$ & $2=14,28 \%$ & $3=21,42 \%$ & $1=7,14 \%$ & $7=50,00 \%$ \\
\hline Csongrád & - & - & $2=28,57 \%$ & $3=42,85 \%$ & $2=28,57 \%$ \\
\hline Fejér & - & $5=50,00 \%$ & $2=20,00 \%$ & $3=30,00 \%$ & - \\
\hline Györ-Moson-Sopron & - & $2=33,33 \%$ & $2=33,33 \%$ & $2=33,33 \%$ & - \\
\hline Hajdú-Bihar & - & $1=12,50 \%$ & $1=12,50 \%$ & $3=37,50 \%$ & $3=37,50 \%$ \\
\hline Heves & - & $1=14,28 \%$ & $3=42,85 \%$ & $3=42,85 \%$ & - \\
\hline Jász-Nagykun-Szolnok & - & $3=27,27 \%$ & $3=27,27 \%$ & $3=27,27 \%$ & $2=18,18 \%$ \\
\hline Komárom-Esztergom & - & $4=50,00 \%$ & $2=25,00 \%$ & $1=12,50 \%$ & $1=12,50 \%$ \\
\hline Nógrád & - & $2=50,00 \%$ & - & $1=25,00 \%$ & $1=25,00 \%$ \\
\hline Pest & $10=20,83 \%$ & $19=39,58 \%$ & $9=18,75 \%$ & $8=16,66 \%$ & $2=4,16 \%$ \\
\hline Somogy & - & $1=20,00 \%$ & - & $3=60,00 \%$ & $1=20,00 \%$ \\
\hline Szabolcs-Szatmár-Bereg & - & - & - & $3=33,33 \%$ & $6=66,66 \%$ \\
\hline Tolna & - & $2=33,33 \%$ & $4=66,66 \%$ & - & - \\
\hline Vas & - & $1=25,00 \%$ & $1=25,00 \%$ & $1=25,00 \%$ & $1=25,00 \%$ \\
\hline Veszprém & $2=40,00 \%$ & $2=40,00 \%$ & $1=20,00 \%$ & - & - \\
\hline Zala & - & - & $1=50,00 \%$ & $1=50,00 \%$ & - \\
\hline
\end{tabular}

Forrás: saját szerkesztés 


\section{Miletics Péter:}

Magyarországi települések vizsgálata közlekedési és távközlési ellátottság alapján

Tér és Társadalom 10. évf. 1996/2-3. 237-243. p.

TÉT 1996 - 2-3

Magyarországi települések..

\section{TÁBLÁZAT}

A megyék településeinek kategóriákra kivetített részesedése

(The share of settlements by counties, by cathegories)

I. kategória

\begin{tabular}{|l|c|c|}
\hline Megye & $\begin{array}{c}\text { Település- } \\
\text { szám }\end{array}$ & $\begin{array}{c}\text { Százalékos } \\
\text { megoszlás }\end{array}$ \\
\hline Pest & 10 & $71,40 \%$ \\
\hline Bács-Kiskun & 1 & $7,15 \%$ \\
\hline Borsod-Abaúj-Zemplén & 1 & $7,15 \%$ \\
\hline Veszprém & 2 & $14,30 \%$ \\
\hline
\end{tabular}

II. kategória

\begin{tabular}{|l|c|c|}
\hline Megye & $\begin{array}{c}\text { Telepúlés- } \\
\text { szám }\end{array}$ & $\begin{array}{c}\text { Százalékos } \\
\text { megoszlás }\end{array}$ \\
\hline Baranya & 2 & $4,08 \%$ \\
\hline Bács-Kiskun & 2 & $4,08 \%$ \\
\hline Borsod-Abaúj-Zemplén & 2 & $4,08 \%$ \\
\hline Fejér & 5 & $10,20 \%$ \\
\hline Györ-Moson-Sopron & 2 & $4,08 \%$ \\
\hline Hajdú-Bihar & 1 & $2,04 \%$ \\
\hline Heves & 1 & $2,04 \%$ \\
\hline Jász-Nagykun-Szolnok & 3 & $6,12 \%$ \\
\hline Komárom-Esztergom & 4 & $8,16 \%$ \\
\hline Nógrád & 2 & $4,08 \%$ \\
\hline Pest & 19 & $38,77 \%$ \\
\hline Somogy & 1 & $2,04 \%$ \\
\hline Tolna & 2 & $4,08 \%$ \\
\hline Vas & 1 & $2,04 \%$ \\
\hline Veszprém & 2 & $4,08 \%$ \\
\hline
\end{tabular}

III. kategória

\begin{tabular}{|l|c|c|}
\hline Megye & $\begin{array}{c}\text { Település- } \\
\text { szám }\end{array}$ & $\begin{array}{c}\text { Százalékos } \\
\text { megoszlás }\end{array}$ \\
\hline Baranya & 1 & $2,56 \%$ \\
\hline Bács-Kiskun & 2 & $5,12 \%$ \\
\hline Békés & 2 & $5,12 \%$ \\
\hline Borsod-Abaúj-Zemplén & 3 & $7,69 \%$ \\
\hline Csongrád & 2 & $5,12 \%$ \\
\hline Fejér & 2 & $5,12 \%$ \\
\hline Györ-Moson-Sopron & 2 & $5,12 \%$ \\
\hline Hajdú-Bihar & 1 & $2,56 \%$ \\
\hline Heves & 3 & $7,69 \%$ \\
\hline Jász-Nagykun-Szolnok & 3 & $7,69 \%$ \\
\hline Komárom-Esztergom & 2 & $5,12 \%$ \\
\hline Pest & 9 & $23,07 \%$ \\
\hline Tolna & 4 & $10,25 \%$ \\
\hline Vas & 1 & $2,56 \%$ \\
\hline Veszprém & 1 & $2,56 \%$ \\
\hline Zala & 1 & $2,56 \%$ \\
\hline
\end{tabular}

Forrás: saját szerkesztés
IV. kategória

\begin{tabular}{|l|c|c|}
\hline Megye & $\begin{array}{c}\text { Település- } \\
\text { szám }\end{array}$ & $\begin{array}{c}\text { Százalékos } \\
\text { megoszlás }\end{array}$ \\
\hline Baranya & 1 & $2,27 \%$ \\
\hline Bács-Kiskun & 1 & $2,27 \%$ \\
\hline Békés & 6 & $13,63 \%$ \\
\hline Borsod-Abaúj-Zemplén & 1 & $2,27 \%$ \\
\hline Csongrád & 3 & $6,81 \%$ \\
\hline Fejér & 3 & $6,81 \%$ \\
\hline Győrr-Moson-Sopron & 2 & $4,54 \%$ \\
\hline Hajdú-Bihar & 3 & $6,81 \%$ \\
\hline Heves & 3 & $6,81 \%$ \\
\hline Jász-Nagykun-Szolnok & 3 & $6,81 \%$ \\
\hline Komárom-Esztergom & 1 & $2,27 \%$ \\
\hline Nógrád & 1 & $2,27 \%$ \\
\hline Pest & 8 & $18,18 \%$ \\
\hline Somogy & 3 & $6,81 \%$ \\
\hline Szabolcs-Szatmár-Bereg & 3 & $6,81 \%$ \\
\hline Vas & 1 & $2,27 \%$ \\
\hline Zala & 1 & $2,27 \%$ \\
\hline
\end{tabular}

V. kategória

\begin{tabular}{|l|c|c|}
\hline Megye & $\begin{array}{c}\text { Település- } \\
\text { szám }\end{array}$ & $\begin{array}{c}\text { Százalékos } \\
\text { megoszlás }\end{array}$ \\
\hline Baranya & 3 & $9,67 \%$ \\
\hline Békés & 2 & $6,45 \%$ \\
\hline Borsod-Abaúj-Zemplén & 7 & $22,58 \%$ \\
\hline Csongrád & 2 & $6,45 \%$ \\
\hline Hajdú-Bihar & 3 & $9,67 \%$ \\
\hline Jász-Nagykun-Szolnok & 2 & $6,45 \%$ \\
\hline Komárom-Esztergom & 1 & $3,22 \%$ \\
\hline Nógrád & 1 & $3,22 \%$ \\
\hline Pest & 2 & $6,45 \%$ \\
\hline Somogy & 1 & $3,22 \%$ \\
\hline Szabolcs-Szatmár-Bereg & 6 & $19,35 \%$ \\
\hline Vas & 1 & $3,22 \%$ \\
\hline
\end{tabular}


A már-már hagyományos Dunántúl-Alföld összehasonlításban - melybe nem számoltuk bele a Pest megyei településeket - az alábbiakat állapítottuk meg. Az első kategóriában gyakorlatilag nem mutatható ki bármilyen előny a dunántúli nagyrégió javára Mindkét térség két-két településsel szerepelt a kategórián belül, habár a Dunántúlon nagyobb település koncentráltság volt kimutatható (mindkét nagyközség Veszprém megyében található). Némi meglepetést keltett Nyékládháza előkelő helyezése, míg a fontos közlekedési csomópont, Solt jó távközlési, közlekedési ellátottsága révén került az első kategóriába.

A második kategóriába tartozó települések között már markánsabbak a regionális szintü különbségek. A kategórián belül az Alföld 11 településsel, míg a Dunántúl 19 nagyközséggel képviseltette magát. (Megjegyezzük, hogy Pest megye önmagában ugyanannyi településsel rendelkezett ebben a kategóriában, mint a Dunántúl.) A Dunántúlon Fejér és Komárom-Esztergom megye helyzete volt a legkedvezőbb a kategórián belül, ami arra utal, hogy az innovációs tengelyen elhelyezkedő települések rendelkeznek a szükséges távközlési és közlekedési infrastruktúrával.

A harmadik kategóriában az Alföld és a Dunántúl közötti eltérések gyakorlatilag elhanyagolhatók, hiszen mindkét nagyrégió közel azonos számú településsel képviseltette magát (Alföld:16, Dunántúl:14). Kimutatható, hogy a kategórián belül más szempontból is a kiegyenlítődés a jellemző. Nem voltak kiugró értékekkel szereplő megyék, a megyei szintü település koncentráció értéke 1-4 között maradt (kivétel ismét Pest megye, amely 9 nagyközséggel szerepelt).

A negyedik kategórián belül már kimutatható volt a regionális eltérés az Alföld javára, mely kétszer annyi településsel rendelkezett (24) a kategórián belül, mint a Dunántúl (12). Ebben a településcsoportban Békés megye rendelkezett a legnagyobb fokú koncentráltsággal (6 nagyközség), míg a Dunántúlon Fejér megye adta a legtöbb települést (3).

Az utolsó, ötödik kategóriában igen markánsan jelentkezett az Alföld-Dunántúl regionális ellentét. A Dunántúl mindössze 6, az Alföld 23 nagyközséggel rendelkezett. Borsod-Abaúj-Zemplén és Szabolcs-Szatmár-Bereg megyék mutatták a legnagyobb település-koncentrációt, ami arra utal, hogy ezek a területek igen hátrányos helyzetben vannak a távközlési és közlekedési infrastruktúra tekintetében.

Összességében kimutatható, hogy a trendek a harmadik kategóriától kezdve az Alföld rovására változtak, egyértelmüen bizonyitva a régió hátrányos helyzetét. Különösen az ország keleti peremvidékén kritikus a települések közlekedési és távközlési ellátottsága, amely önmagában is komolyan akadályozhatja a települések további fejlődését. A Dunántúlon a helyzet jobb, de itt is vannak elmaradottabb területek, mig az innovációs tengelyek közelében a nagyközségek rendelkeznek a fejlödéshez szükséges közlekedési és távközlési rendszerekkel. Az is kimutatható, hogy a dunántúli megyékben kiegyenlítettebb a helyzet, kisebbek a fejlettségi különbségek az egyes megyéken belül. Az Alföld szélsőségesebb, bár a peremvidékeken kimutatható egy sajátos, rendkívül alacsony szinten realizálódó fejlettségi-ellátottsági kiegyenlítettség. Pest megye fejlett, jó ellátottsággal rendelkezik, különösen az agglomerációs övezetben, illetve annak határán. Az agglomerációs központtól távolodva az ellátottság színvonala csökkenö tendenciát mutat.

A magyar települések közlekedési és távközlési ellátottsága nem egyenletes és összességében az európai átlaghoz képest alacsonynak mondható. Véleményünk szerint 
fontos lenne mindezek további fejlesztése nemcsak az Európához történő felzárkózás miatt, hanem az országon belüli regionális eltéréseket mérséklése érdekében is.

\section{Jegyzetek}

${ }^{1}$ Hangsúlyoznunk kell, hogy számos település értékpontjait nagyban megnövelték a Budapestről rendszeresen kijáró "kék buszok", valamint a HÉV járatok. Mindez arra utal, hogy a föváros közelében elhelyezkedő nagykőzségeknek (általában) igen jók a kơzlekedési és távkơzlési kapcsolatai Budapesttel, de ez nem feltétlenul erősíti ezen telepulések onálló térszervező funkcióit.

\section{Irodalom}

A Magyar Köztársaság Helységnévtára 1995, Központi Statisztikai Hivatal, Budapest. 1995.

A Magyar Távközlési Részvénytársaság Hivatalos Elófizetöi Névsora. (Megyei Telefonkonyvek) 1995/96. Budapest. MATÁV és Magyar Telefonkönyvkiadó Kft. 1995.

Hivatalos Autobusz Menetrend 1-20. kôtet, 1995. május 28.-1996. június 1., Budapest. Volán Egyesülés 1995. Magyar Államvasutak, Hivatalos Menetrend. 1995. május 28.-1996. június 1., MÁV. Budapest. 1995.

Pannon GSM Hálózati Térkép 1995. március 31.

WESTEL GSM Hálozati Térkép 1994. december 31

\section{Abstract}

Transportation and telecommunication systems, as part of the infrastructure, play a considerable role in how individual settlements are judged. They increase the speed of the flows of information that gain greater and greater importance, in general, they improve the possibilities of information exchange. Furthermore they are dominant for the population, enabling them to expand their spatial moves and thus the increase in the mobility index of the population.

The mere existence of these infrastructural elements does not enable a certain settlement to provide for independent space organising functions, but their possible lack has a much more negative impact on how the settlements are perceived than the really existing problems deriving from their maintenance or establishment.

The selection of the 177 villages involved in the survey took place by preliminary agreements. Our purpose was to put the large villages by some arbitrarily chosen indices into a hierarchical order. 